Article

\title{
Sustainable Infrastructure in Conflict Zones: Police Facilities' Impact on Perception of Safety in Afghan Communities
}

\author{
Rosa T. Affleck ${ }^{1, *(1)}$, Kevin Gardner $\left.{ }^{2} \mathbb{(}\right)$, Semra Aytur ${ }^{3}$, Cynthia Carlson ${ }^{4} \mathbb{(}$, Curt Grimm $^{5}$ and \\ Elias Deeb ${ }^{1}$ \\ 1 Engineer Research and Development Center, Cold Regions Research and Engineering \\ Laboratory (ERDC-CRREL), U.S. Army Corps of Engineers, Hanover, NH 03755, USA; \\ Elias.J.Deeb@usace.army.mil \\ 2 Civil and Environmental Engineering Department, University of New Hampshire (UNH), Durham, NH \\ 03824, USA; Kevin.Gardner@unh.edu \\ 3 Department of Health Management and Policy, College of Health and Human Services, University of New \\ Hampshire (UNH), Durham, NH 03824, USA; Semra.Aytur@unh.edu \\ 4 Civil Engineering Department, Merrimack College, North Andover, MA 01845, USA; \\ carlsonc@merrimack.edu \\ 5 Carsey School of Public Policy, University of New Hampshire (UNH), Durham, NH 03824, USA; \\ Curt.Grimm@unh.edu \\ * Correspondence: Rosa.T.Affleck@usace.army.mil; Tel.: +603-464-4662
}

Received: 25 February 2019; Accepted: 30 March 2019; Published: 9 April 2019

\begin{abstract}
The notion of sustainable infrastructure for the delivery of social services is to fulfill basic human needs; in war-torn societies, human safety is a critical basic need. The relationship between sustainable infrastructure development and human safety remains underresearched in Afghan neighborhoods. Therefore, this study examined the effectiveness of the police facilities constructed for stability enhancement in Afghan communities. To do so, this study used Afghans' polling datasets on the police presence and the public safety perceptions, including newly collected survey data related to the influence of the police facilities on human safety and other factors contributing to the neighborhoods' well-being. The datasets are organized with a multilevel structure in which different individuals are sampled within neighborhoods and analyzed using a multilevel model approach to capture the randomness of the responses. The results showed that police facilities are more important to perceptions of safety in less safe areas and that Afghans in villages perceived themselves as safer than in urban areas, relative to their own immediate region. Those perceiving themselves as being safer were older, more highly educated, and widowed respondents. Overall, Afghans perceived the police facilities as institutional symbol for promoting improvements and opportunities for fulfilling basic human safety needs.
\end{abstract}

Keywords: Afghanistan; infrastructure development; perceived safety; police confidence; resilience; stability; sustainability; trust; war-torn environment

\section{Introduction}

Fundamental requisites for nation-building efforts typically include establishing basic services and functional security, governance, and economic and infrastructure systems in conflict zones [19]. The constructive outcomes from these extensive efforts are deeply interrelated for encouraging conflict-ridden states to develop and attain stable, safe communities that can enable sustainable development. Infrastructure development can provide economic stabilization by helping a nation 
develop both their capability and capacity $[2,10]$ to become an emerging society $[4,9,11]$. An extensive example of such nation-building efforts was the stability operations in Afghanistan, in which the United States Government (USG) invested enormous amounts of funds and military resources for reconstruction (i.e., restoration of war-torn societies) and infrastructure development (i.e., creation of new institutions) since 2002 [12,13]. Part of the infrastructure development efforts for stability operations investment was for the USG and international donors to construct police stations and to establish the Afghan National Police (ANP) in anticipation of positive outcomes, in part due to the presence of the ANP. Likewise, the aftereffect expected was that the Afghan police would demonstrate the functional capacity and capabilities to run their newly restored security infrastructure, reestablishing and maintaining a safe and secure environment for the population.

The term security and safety are used interchangeably within this paper, referring to human security [14-17] and the fundamental interconnected psychological and socioeconomic needs for pursuing basic protection goals of self-reliance [16] and protecting people's well-being [17]. Specifically in this study, the term safety describes the factors for satisfying the human security needs that are traditionally generated from infrastructure development, creation of institutions and are advocated by law enforcement's providing peace and order to make people feel secure. Infrastructure development has fundamentally been a catalyst for creating stable and resilient communities [2,18-21], as well as building sustainable societies [22-25].

The resilience framework is recognized as the ability of communities to collectively recover from or adapt to various perturbations: security threats, disasters, adversity, or environmental stress [18-20,26-30]. The term stability is conceptually associated with outcomes in remaining a stable state when disturbed by some transient external force [31] by using a comprehensive approach for restoring peace or social order [32], for drawing cooperation [33], and for developing capability or capacity [10]. Through adjustment from the dynamic recovery responses a new condition is created, and an equilibrium condition of a system is potentially transformed [28,30,34]. Stability agents are related to the structures and processes for which societies have shared purpose or ownership [35], thereby producing influence for their collective action [34]. Social relation attributes, such as cohesion, participation, representation, deliberation, accountability, control or empowerment, social justice, rules, norms, and promotion of trust, would boost resilience [27,30,35-38] or growth, as well as accommodate a range of social outcomes [39-42] and nonphysical factors for sustainability [23-25].

The construction of hard infrastructure (such as having a police facility), providing an anchor institution (with anticipated collective action from the police forces and their interaction with the community), is considered a catalyst for enabling the recovery and stability of public safety. These social relations could stimulate benefits and cohesion in the community [23-25,39-42]. For community development, the capacity to leverage resources from formal institutions is a key function in linking social capital and growth [2,25,39-42]. Having embedded resources (such as a police station) occupied by individuals with a collective mission (such as the police) in accessible locations would conceivably exert influence in the community. In the context of a police facility, the more accessible a police station is to the community, the better the police could mobilize to serve the community, providing social protection and safety. As an infrastructure source that provides for public stability, how effective have these ANP facilities been in collectively influencing their neighborhood's safety and local growth?

Given the complexity inherent in infrastructure development and community resilience in war-torn environments, this study consisted of a quantitative analysis of residents' perception of safety and other social well-being factors associated with having the police facilities. Using a hierarchical generalized linear model (HGLM), this study assessed the placement of police stations and the perceptions of safety in the surrounding Afghan neighborhoods in eastern and northern Afghanistan as well as the broader understanding of the interaction between the community and police personnel for fostering social impact.

Section 2 of the paper provides a brief introduction on the rebuilding of the ANP, its impediments, and challenges. The study areas are briefly described in Section 3 (further details are in Affleck 2018, 
ref. [43]). The subsequent Sections 4-6 discuss the perception measures, describe the hierarchical models to analyze the data, and summarize the results of the association between perceived neighborhood safety and resiliency due to the influence of having the police facilities in the neighborhoods, respectively. Finally, Sections 7 and 8 highlight the most relevant summary and conclusions drawn from the analyses.

\section{Rebuilding Afghan Police and Security}

The overall security reform of rebuilding the ANP was infused with challenges. Experts in security reform claimed that the rebuilding of the ANP was marred by setbacks that greatly limited its impact in creating effective, democratically accountable, and rights-respecting police forces [44-47]. A vast number of these initial police recruits in 2002 that were conscripted into the armed services were untrained former militants, and most were illiterate $[47,48]$ as literacy rates for males had fallen to $18 \%$ by 2001 [49]. The police forces lacked formal training, facilities, equipment, uniforms, and public trust. Additionally, ethnic imbalance was an issue as most of the senior police posts were represented by one particular ethnic group.

Thousands of police received some form of training by the end of 2005 [45], but fielding the trained police was problematic due to a lack of communication and transportation equipment, crumbling infrastructure, and poor police pay. According to Sedra [45], a synchrony of processes, including resources for training and required equipment, is a must for security reform to succeed. In the past few years, the USG has continued to support personnel reforms, supply police equipment, rehabilitate vital infrastructure, and underwrite continued training for creating security forces [50,51] that are both efficient and effective to sustainably meet the security needs of a population.

Adding to the complexity of the progress, Afghan security forces have been continually hampered by insurgent disruptions. Nearly two-thirds of the security forces killed by insurgent attacks between January 2007 and July 2008 were Afghan police [52]. In the midst of the Afghanistan effort from 2002 to 2014, scholars from a wide range of disciplines outlined various ways to improve security while creating alliances and gathering support from local people [52-54], and defined the principles of state building as enhancing "winning the peace" while stabilizing chaotic regions [9] and suppressing violence, preserving life, liberty, and property [55,56]. Fluctuating security forces in Afghanistan has impacted public confidence. In tandem, the perceived insecurity has been regionally salient along with the inherent challenges in rebuilding the ANP. However, reports have shown that police are winning the confidence of ordinary people [57]; polling data continued to show robust public support for a strong central government, and more Afghans have expressed positive views in the security forces than those that criticized them, including positive perceptions of the ANP for providing local security and stability $[52,58]$.

This study focused on the neighborhood scale where police facilities built for ANP exist, and assumed that the impact of the police facilities' influence on the perceived neighborhood safety and resiliency was tied to the characteristics or type of neighborhoods and density of the local population, as well as to the facilities' characteristics. Along with existing survey data, a set of primary survey data was collected to examine the impact of the facilities on people's perception of safety and probable neighborhood improvements. In addition, Affleck [43] documented remote sensing and other geospatial data used to triangulate the survey data described in this paper. The associated improvements were analyzed and bounded within the time frame of this study. Potential confounding factors unique to the region were excluded, such as security disruption by militants, which created incidents of security interruption and disrupted people's feeling of safety as the Afghan Police struggled for security progress in the community.

\section{Study Areas}

Affleck [43] compared existing regional perceptions of safety from the Asia Foundation [58] survey to narrow down two areas for exploring the hypothesis of varying community safety conditions and 
patterns. Alias names (e.g., SA\#1, considered a "safer" area, and SA\#2, inferred to be a "less safe" area) were assigned for the two communities selected in this study and police facilities were undisclosed due to political sensitivity and residents' protection [43]. The study areas were divided into rectangular grid patterns by splitting them into subneighborhoods ( $S B_{-} i d$, Table 1$)$ and representing the gender sampling for random-walk approach, described in Section 4.

Table 1. Community and police survey distribution for both study areas.

\begin{tabular}{|c|c|c|c|c|c|c|}
\hline Location & $\begin{array}{c}\text { Neighborhood } \\
\text { Block }\left(S B \_i d\right)\end{array}$ & $\begin{array}{l}\text { Sampling } \\
\text { Unit }(S P)\end{array}$ & $\begin{array}{l}\text { Number of } \\
\text { Samples, N }\end{array}$ & Gender & Mean Age & $\begin{array}{c}\text { Estimated } \\
\text { Sample Weight }\end{array}$ \\
\hline \multirow{11}{*}{$\begin{array}{l}\text { Study Area } 1 \\
\text { (SA\#1) }\end{array}$} & N1 & 1 & 10 & Female & 33.3 & $0.04^{a}$ \\
\hline & N2 & 2 & 10 & Male & 38.0 & $0.05^{\mathrm{a}}$ \\
\hline & N3 & 3 & 10 & Female & 29.5 & $0.05^{\mathrm{a}}$ \\
\hline & N4 & 4 & 10 & Male & 37.1 & $0.04^{\mathrm{a}}$ \\
\hline & N5 & 5 & 10 & Female & 34.2 & $0.07^{\mathrm{a}}$ \\
\hline & N6 & 6 & 10 & Male & 50.0 & $0.23^{a}$ \\
\hline & N7 & 7 & 10 & Female & 26.5 & $0.06^{\mathrm{a}}$ \\
\hline & N8 & 8 & 10 & Male & 36.4 & $0.50^{a}$ \\
\hline & \multicolumn{2}{|c|}{ Facility A } & 10 & Male & 44.1 & $0.50^{b}$ \\
\hline & \multicolumn{2}{|c|}{ Facility B1 } & 5 & Male & 39.8 & $0.20^{b}$ \\
\hline & \multicolumn{2}{|c|}{ Facility B2 } & 5 & Male & 38.0 & $0.20^{\mathrm{b}}$ \\
\hline \multirow{12}{*}{$\begin{array}{c}\text { Study Area } 2 \\
(\mathrm{SA \# 2)}\end{array}$} & \multirow[b]{2}{*}{ E1 } & 1 & 10 & Male & 32.3 & \multirow[b]{2}{*}{$0.05^{\mathrm{a}}$} \\
\hline & & 2 & 10 & Female & 23.4 & \\
\hline & E2 & 3 & 10 & Male & 31.9 & $0.02^{\mathrm{a}}$ \\
\hline & \multirow{2}{*}{ E3 } & 5 & 10 & Male & 28.3 & \multirow{2}{*}{$0.01^{\mathrm{a}}$} \\
\hline & & 6 & 10 & Female & 28.1 & \\
\hline & E5 & 7 & 10 & Male & 39.0 & $0.01^{\mathrm{a}}$ \\
\hline & E6 & 4 & 10 & Female & 26.8 & $0.02^{\mathrm{a}}$ \\
\hline & E7 & 8 & 10 & Female & 31.3 & $0.01^{\mathrm{a}}$ \\
\hline & \multirow{2}{*}{ E8 } & 9 & 10 & Male & 29.8 & \multirow{2}{*}{$0.04^{\mathrm{a}}$} \\
\hline & & 10 & 10 & Female & 29.1 & \\
\hline & \multicolumn{2}{|c|}{ Facility A1 } & 10 & Male & 35.3 & $0.20^{b}$ \\
\hline & \multicolumn{2}{|c|}{ Facility A2 } & 10 & Male & 34.2 & $0.20^{b}$ \\
\hline
\end{tabular}

a Calculated mean sample weight for each sampling block is based on the ratio of number of surveys and total number of households per neighborhood. ${ }^{b}$ Calculated mean sample weight for each police facility is based on the ratio of police respondents' estimation of number of workforce staff in the facility to the number of police respondents.

SA\#1 is located on the southern outskirts of a city in a northern provincial area. The neighborhood is mainly suburban with relatively open and barren land to the southern city limit. The entire SA\#1 is approximately $5 \mathrm{~km}$ in the east-west direction and $4 \mathrm{~km}$ in the north-south direction. SA\#1 is divided into eight neighborhood blocks, following the directions of the majority of the roads. The size of the neighborhood blocks range from 1.7 to $2.6 \mathrm{~km}^{2}$. Three police facilities are located in the vicinity of SA\#1: one is situated inside one of the western neighborhood blocks and two police facilities are outside the neighborhood blocks to the southwest. They are approximately $4.5 \mathrm{~km}$ from each other.

SA\#2 is located on the eastern edge of its respective urban/suburban area with agricultural areas abound in an eastern provincial area. The entire SA\#2 is within a strip approximately $6 \mathrm{~km}$ in the east-west direction and $2.4 \mathrm{~km}$ in the north-south direction. SA\#2 is divided into seven neighborhood blocks, which are divided equally such that each neighborhood block is $1.44 \mathrm{~km}^{2}$. Four police facilities are situated in the vicinity: two police stations are within SA\#2 and two other police facilities are located outside the neighborhood blocks on the southeast side.

\section{Data}

Actual data collection in war-torn countries is recognized as an extremely challenging undertaking, particularly in Afghanistan [59,60]. Unlike in the Western world, deploying and disseminating personnel for survey data collection in Afghanistan required a well-orchestrated coordination among government and local agencies because of instability, language, and attempts at cultural appropriateness. Thus, a reliable data collection agency with in-country affiliations familiar with the area and the local language and culture is ultimately required to minimize residents' lack of trust of 
survey personnel, residents' fear of discovery due to lack of anonymity, and other issues associated with sociopolitical sensitivities around the data. Afghans are familiar with polls, especially pertaining to political, economic, and other social inquiries since the USG, United Nations (UN), and international partners have conducted surveys in Afghanistan since 2003. Although surveys, such as the ones collected by the Asia Foundation (TAF), and the USG project called Measuring Progress in Conflict Environments (MPICE) were extensive, the social impact of specific infrastructure developments has been unexplored and unanalyzed at a neighborhood level. This study collected primary survey data and used existing polling datasets to provide background information related to the regional perceptions of the police presence and the public safety conditions.

For primary survey data, two sets of questionnaires were created: one for the law enforcement staff (police officers survey) and the other designed for the local population around the neighborhood near the police facilities (community survey). The intent of the survey was to gain a broader understanding of how the placement of police stations in the area has affected the safety of the surrounding community and fostered interaction between the community and police personnel for resilience capacities. The questionnaires used the phrase "having the ANP facilities in your community, or, having the ANP facilities at their present locations" with mostly closed-type questions using polytomous (i.e., Likert-type, or a rating scale with more than two categories) responses and a few dichotomous (i.e., yes/no) questions for verification [43]. The police survey questionnaires were reviewed and pretested by US law enforcement officers who served in Afghanistan and worked with the Afghan police. The format and questions in the questionnaires were reviewed for local culture appropriateness then translated to the local languages, and the survey was conducted in the local languages by the contracted Afghan survey staff.

The community surveys were collected within each neighborhood block. This sampling method was used to isolate and capture the subpopulation according to the following steps. First, a starting point was arbitrarily selected to serve as the random-walk starting point for each neighborhood block $\left(S B \_i d\right)$. Second, a representative sampling point unit $(S P)$ was randomly assigned in the sample plan as either a male $S P$ or a female $S P$, meaning that only respondents of the assigned gender would be interviewed within each $S B \_i d$. This was done to allow for gender-matched interviewing, where the interviewer and the respondent were of the same gender. This was required due to cultural constraints in Afghan society that restrict interactions between men and women not in the same family. Third, the interviewer performed a random-walk pattern from the selected starting point and continued sampling every fifth house on the right towards the center of their assigned $S B \_i d$. After selecting a household, interviewers selected a random respondent within the household; male household members were listed for designated male $S P$ and vice versa for female $S P$ selection. A prescribed number of survey samples was assigned per $S P$ primarily due to logistics and a set cost of the survey number; a similar setup was used in previous surveys for TAF and MPICE projects in Afghan neighborhoods. The individual household coordinates were undisclosed for confidentiality, privacy, and safety. For SA\#1, 10 samples were collected, representing 10 households per SP (Table 1). For $S A \# 2$, sampling was attempted for each $S B \_i d$ to have both male $S P$ and female $S P$ surveys. Due to interviewers missing some random-walk starting point, the dataset only represented three $S B$ ids with both gender responses (Table 1). Sampling collection for SA\#1 was conducted in September 2016 and in March 2017 for SA\#2.

The police surveys were randomly given to police officers of middle- or higher-level ranks. The police survey for SA\#1 was collected in three police facilities in the neighborhood (Table 1). Construction of one facility was completed in May 2009 and in October 2011 for the other two facilities located in the southwest portion of the neighborhood. The police survey in SA\#2 was collected in two police districts (Table 1). Construction of the facilities was completed in January 2007 and in 2011. Also, there are two other ANP facilities constructed outside the southwest periphery of SA\#2; there are other police facilities within $3 \mathrm{~km}$ outside the study area that may have some influence on security, particularly in the nearby neighborhood. In each study area, the combined community and police surveys are labeled as variables following the community question numbers (i.e., $P 3, P 4$, etc.) followed 
with a shortened description of variables (Tables 2 and 3) that are explicitly described in the following sections. The distribution and the bivariate correlation estimation using Spearman's coefficient rho to show the general differences and the statistical relationships for survey data collected from the police and neighborhoods at each study area were analyzed and can be found in Affleck 2018 [43].

Table 2. Descriptive statistics for dependent variables of police facility contribution to the community collected in September 2016 for SA\#1 and in March 2017 for SA\#2 used in U-A, RI-A, U-B, and RI-B models.

\begin{tabular}{|c|c|c|c|c|c|c|c|}
\hline Dependent Variables & Responses & $\mathbf{N}$ & $\%$ & Mean & SD & Min & Max \\
\hline \multirow{4}{*}{$\begin{array}{l}\text { P7e: People are now feeling safer (as } \\
\text { the dependent variable for Model A) }{ }^{\text {a }}\end{array}$} & $1=$ strongly agree & 66 & 30.1 & \multirow{4}{*}{2.1} & \multirow{4}{*}{0.9} & \multirow{4}{*}{1} & \multirow{4}{*}{4} \\
\hline & $2=$ agree & 86 & 39.3 & & & & \\
\hline & $3=$ neutral & 49 & 22.4 & & & & \\
\hline & $4=$ disagree & 18 & 8.2 & & & & \\
\hline \multirow{4}{*}{$\begin{array}{l}P 13 a \text { : Security to the community (as } \\
\text { the dependent variable for Model B) }\end{array}$} & $1=$ strongly agree & 101 & 46.1 & \multirow{4}{*}{1.7} & \multirow{4}{*}{0.7} & \multirow{4}{*}{1} & \multirow{4}{*}{3} \\
\hline & $2=$ agree & 92 & 42.0 & & & & \\
\hline & $3=$ neutral & 26 & 11.9 & & & & \\
\hline & $4=$ disagree & 0 & 0.0 & & & & \\
\hline
\end{tabular}

a The hierarchical generalized linear model (HGLM) is set with a "descending" option in the response for models $\mathrm{A}-\mathrm{B}$ to reverse the order of the polytomous data for the perceived dependent variables.

Table 3. Descriptive statistics for independent variables used in RI-A and RI-B models.

\begin{tabular}{|c|c|c|c|c|c|}
\hline Independent Variables & $\mathbf{N}$ & Mean & SD & Min & Max \\
\hline Age & 220 & 33.5 & 11.7 & 18 & 80 \\
\hline Gender: 1 = Male $(59 \%), 2=$ Female $(41 \%)$ & 220 & & & & \\
\hline Region: 1 = SA\#1 (safer) and $0=\mathrm{SA \# 2} \mathrm{(less} \mathrm{safe)}$ & 2 & & & & \\
\hline Neighborhood type ${ }^{\mathrm{a}, \mathrm{b}}: 1=$ urban core, $2=$ new urban, $3=$ suburban & 220 & & & & \\
\hline Population density grouping $\mathrm{b}: 1=$ populated, $0=$ unpopulated & 220 & & & & \\
\hline Estimated number of residential dwellings ${ }^{b}$ & 220 & 504 & 385.5 & 20 & 1356 \\
\hline a1: Distance centroid-police $(\mathrm{km})^{\mathrm{b}}$ & 16 & 1.2 & 0.9 & 0.4 & 3.2 \\
\hline a2: Proximity $(\mathrm{km}) \mathrm{b,c}$ & 18 & 1.4 & 0.7 & 0.4 & 2.9 \\
\hline $\begin{array}{c}P 7 b \text { : Police facility is accessibly located for local citizens }(1=\text { strongly agree, } 2=\text { agree, } 3=\text { neutral, } 4 \\
=\text { disagree })\end{array}$ & 220 & 2.1 & 0.9 & 1 & 4 \\
\hline $\begin{array}{c}\text { P7a: Police facility is in a suitable location for providing police }(1=\text { strongly agree, } 2=\text { agree, } 3= \\
\text { neutral, } 4=\text { disagree })\end{array}$ & 220 & 2.1 & 1.0 & 1 & 4 \\
\hline$P 7 c$ : People have been report crime $(1=$ strongly agree, $2=$ agree, $3=$ neutral, $4=$ disagree $)$ & 220 & 2.1 & 1.0 & 1 & 4 \\
\hline $\begin{array}{c}\text { P10: Level of trust in the local police force to protect people's personal safety }(1=\text { more trust, } 2= \\
\text { same level of trust, } 3=\text { less trust })\end{array}$ & 220 & 1.5 & 0.6 & 1 & 3 \\
\hline $\begin{array}{l}\text { P16: People's confidence in the police }(1=\text { great deal of confidence, } 2=\text { some confidence, } 3=\text { slight } \\
\text { confidence, } 4=\text { not very much confidence })\end{array}$ & 220 & 2.1 & 1.1 & 1 & 4 \\
\hline P18a: Afghan people involvement in building the police facilities $(0=$ no, $1=$ yes $)$ & 220 & 0.5 & 0.5 & 0 & 1 \\
\hline $\begin{array}{l}\text { P11: Rate of present level of safety relative to the past }(1=\text { much safer, } 2=\text { slightly safer, } 3=\text { no } \\
\text { change, } 4=\text { somewhat less safe })\end{array}$ & 220 & 2.1 & 1.1 & 1 & 4 \\
\hline $\begin{array}{c}\text { P17: Security operations are sufficient to keep crime in the area at an acceptable level }(0=\text { no, } 1= \\
\text { yes })\end{array}$ & 220 & 0.7 & 0.5 & 0 & 1 \\
\hline A4: Growth ${ }^{\mathrm{b}, \mathrm{d}}, \%$ & 220 & 6.4 & 3.3 & 0.2 & 12.1 \\
\hline A5: Growth indicator b,d: $(1=$ Growth $>10 \%, 2=$ growth of $2-10 \%, 3=$ growth $<2 \%)$ & 220 & 2.0 & 0.5 & 1 & 3 \\
\hline P12: Population in the community has changed $(1=$ increased, $2=$ stayed the same, $3=$ decreased $)$ & 220 & 1.6 & 0.6 & 1 & 3 \\
\hline P13b: Income (i.e., jobs) to the community $(1=$ strongly agree, $2=$ agree, $3=$ neutral, $4=$ disagree $)$ & 220 & 2.2 & 1.0 & 1 & 4 \\
\hline $\begin{array}{c}\text { P13c: New businesses have been created since this facility was established }(1=\text { strongly agree, } 2= \\
\text { agree, } 3=\text { neutral, } 4=\text { disagree })\end{array}$ & 220 & 2.1 & 1.0 & 1 & 4 \\
\hline P13d: Community improvement to the area $(1=$ strongly agree, $2=$ agree, $3=$ neutral, $4=$ disagree $)$ & 220 & 2.0 & 0.8 & 1 & 4 \\
\hline $\begin{array}{c}P 13 h \text { : Helped people gain skills, employment, etc. }(1=\text { strongly agree, } 2=\text { agree, } 3=\text { neutral, } 4= \\
\text { disagree })\end{array}$ & 220 & 2.0 & 0.8 & 1 & 4 \\
\hline $\begin{array}{c}\text { P13e: Reestablished the police in the community }(1=\text { strongly agree, } 2=\text { agree, } 3=\text { neutral, } 4= \\
\text { disagree })\end{array}$ & 220 & 2.0 & 0.8 & 1 & 4 \\
\hline $\begin{array}{c}\text { P13f: Promoted patriotism in the community }(1=\text { strongly agree, } 2=\text { agree, } 3=\text { neutral, } 4= \\
\text { disagree })\end{array}$ & 220 & 2.0 & 0.8 & 1 & 4 \\
\hline $\begin{array}{c}\text { P13g: Promoted local and national identity and pride }(1=\text { strongly agree, } 2=\text { agree, } 3=\text { neutral, } 4= \\
\text { disagree })\end{array}$ & 220 & 1.9 & 0.8 & 1 & 4 \\
\hline
\end{tabular}

a Two neighborhood type variables were used: One neighborhood type variable has three categories $(1=$ urban core, $2=$ new urban, $3=$ suburban). The other neighborhood type variable has two categories $(1=$ urban core and new urban, 0 = suburban). ${ }^{b}$ Methodology and analysis for these variables can be found in Affleck 2018 [43]. ${ }^{c}$ Both the proximity measurements were used: distance from the closest police facility to the representative respondents' locations, and the distance from starting point for each neighborhood block where a survey sample was collected to the closest police facility. ${ }^{\mathrm{d}}$ Objective growth using remote sensing data between two time periods (August 2010 and January 2014 for Study Area 1 (3.3 years) and February 2009 and October and December 2013 for Study Area 2 (nearly 4 years)) (Affleck 2018 [43]). 


\subsection{Perceived Level of Safety}

Most Western studies using survey data examined police-related influence on the quality of life and neighborhood characteristics [61], on public support for shaping on policing activities [62], and on crime-related public safety opinions in rural areas [63]. Residents in disadvantaged neighborhoods in various racial groups typically expressed dissatisfaction with the police impacting residents' sense of safety [63]. A sense of safety would provide people the ability to move, interact, and transact freely without fear and would broaden both social and economic security $[11,16,17,56]$, as well as the fundamental part of social sustainability [22-25]. In times of emergency or periods of social disorganization and in the absence of physical safety or civil protection-due to war, natural disaster, violence, etc.-citizens are deeply concerned about their personal safety and protection. For Afghans, security had been disrupted, civil protection had been neglected, and freedoms were impaired. The perceived level of safety is measured in questions P7e and P13a in Table 2 and P11 and P17 in Table 3.

The Asia Foundation (TAF) has conducted regionwide public opinion surveys annually since 2004 that pertain to capacity building, state building, political progress, and human security in Afghanistan. Security-related questions were specific to people's personal safety, experience, and reporting of crime and violence, perceptions of the security forces, reconciliation practices (i.e., confidence in the peace processes), fear of encountering armed forces, and knowledge and perceptions of outside threats. The particular TAF assessment relevant to this study included surveys on Afghan police performance and social perceptions of security, such as fear for safety, citizen's satisfaction, crime victimization, and level of confidence (Table 4, renumbered as TAF- $a$, TAF- $b$, TAF-c, and TAF- $d$ with corresponding sociodemographic variables of the respondents), providing contextual understanding of the regional security conditions for the study regions.

Table 4. Descriptive statistics for variables from The Asia Foundation 2012 Data used for U-C and RI-C models.

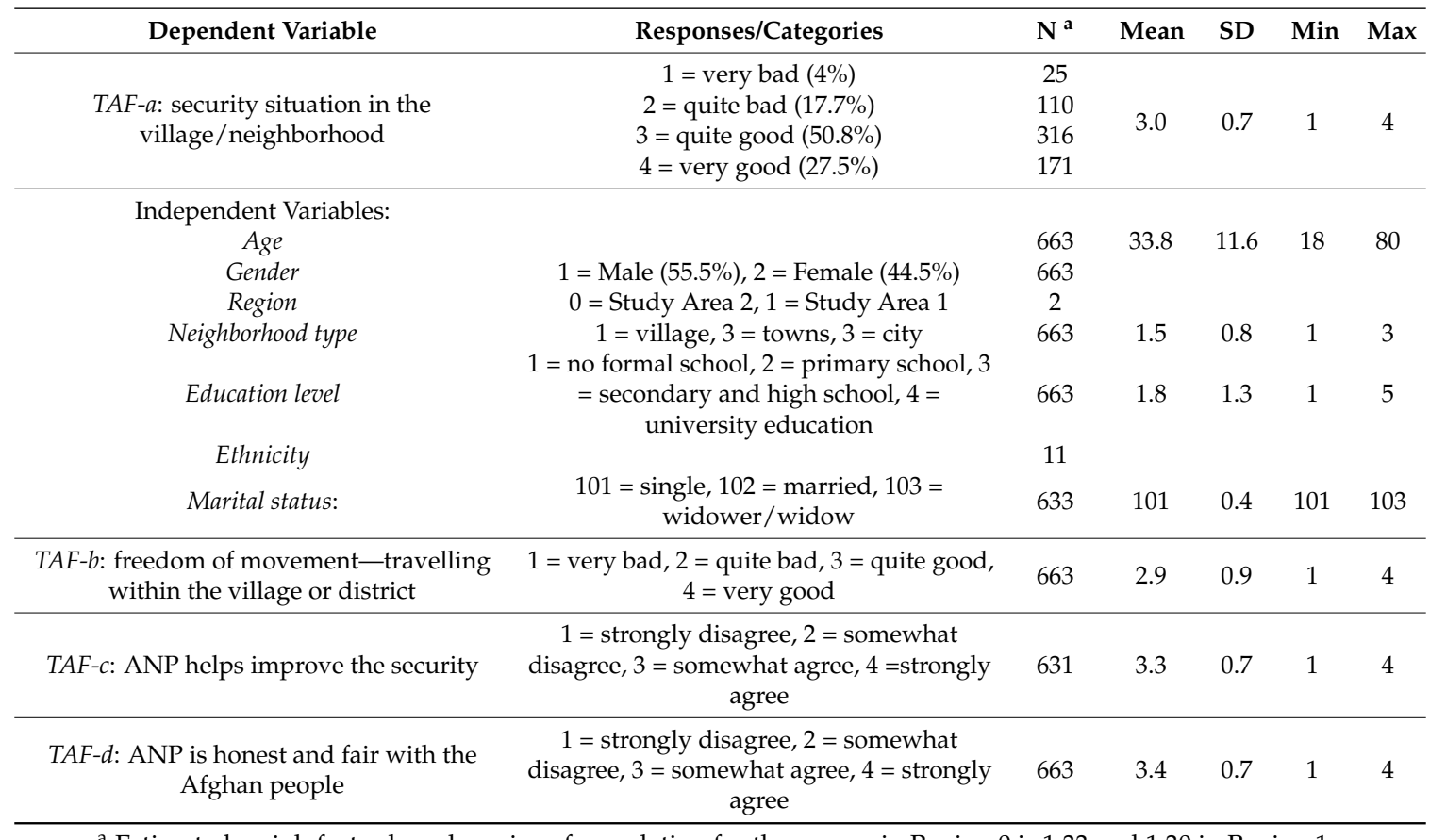

${ }^{\mathrm{a}}$ Estimated weigh factor based on size of population for the survey in Region 0 is 1.33 and 1.30 in Region 1.

Similarly, another survey by the USG was conducted in 2012 to measure outcomes, effectiveness, and progress for efforts or investments during stabilization and reconstruction in places prone to or emerging from conflict $[49,64]$. Traditionally, USG agencies would measure outputs in terms of quantity (i.e., number of schools built, miles of roads paved, or numbers of police trained) and not a quantitative 
indication or feedback on major programs aimed towards social stability. MPICE was developed for USG policy makers to measure social sector impacts by using perception data with indicators in five sectors: a safe and secure environment, political moderation and stable governance, rule of law, sustainable economy, and social well-being [49,64]. The relevant MPICE questions were obtained for the study areas (Table 5), as well as the sociodemographic variables and neighborhood type.

Table 5. Descriptive statistics for variables from MPICE 2012 data used for models U-D and RI-D.

\begin{tabular}{|c|c|c|c|c|c|c|c|}
\hline Dependent Variable & Responses/Categories & $\mathbf{N}^{\mathbf{a}}$ & $\%$ & Mean & SD & Min & Max \\
\hline $\begin{array}{l}M-i \text { : security condition in the } \\
\text { village/neighborhood }\end{array}$ & $\begin{array}{c}1=\text { poor }(2.9 \%) \\
2=\text { fair }(24.5 \%) \\
3=\operatorname{good}(51.9 \%) \\
4=\text { excellent }(20.7 \%)\end{array}$ & $\begin{array}{c}9 \\
77 \\
163 \\
65\end{array}$ & $\begin{array}{c}2.9 \\
24.5 \\
51.9 \\
20.7\end{array}$ & 2.9 & 0.7 & 1 & 4 \\
\hline \multicolumn{8}{|l|}{ Independent Variables: } \\
\hline Age & & 314 & & 31.3 & 10.8 & 18 & 85 \\
\hline Gender & $1=$ Male $(50.6 \%), 2=$ Female $(49.4 \%)$ & 314 & & & & & \\
\hline Region & $1=$ Study Area $1,0=$ Study Area 2 & 2 & & & & & \\
\hline Neighborhood type & $\begin{array}{c}1=\text { city, } 0=\text { village } \\
1=\text { no formal school }, 2=\text { up to } 5 \text { years, } 3\end{array}$ & 314 & & 0.2 & 0.4 & 1 & 2 \\
\hline Education level & $\begin{array}{c}=6-8 \text { years, } 4=9-10 \text { years, } 5=11-12 \\
\text { years, } 6=\text { vocational }\end{array}$ & 314 & & 2.0 & 1.5 & 1 & 6 \\
\hline Ethnicity & 7 kinds of ethnic groups & 314 & & & & & \\
\hline Marital status & $\begin{array}{c}1=\text { married }, 2=\text { widowed, } 3=\text { divorced, } \\
4=\text { single }\end{array}$ & 314 & & 1.5 & 1.1 & 1 & 4 \\
\hline $\begin{array}{l}\text { M-ii: level of security in area compared to } \\
\text { six month ago }\end{array}$ & $\begin{array}{c}1=\text { gotten somewhat worse, } 2=\text { stayed } \\
\text { about the same, } 3=\text { gotten somewhat } \\
\text { better, } 4=\text { gotten much better }\end{array}$ & 314 & & 2.9 & 0.8 & 1 & 4 \\
\hline $\begin{array}{l}\text { M-iii: safe or unsafe you feel when you are } \\
\text { at home }\end{array}$ & $\begin{array}{c}1=\text { somewhat unsafe or not at all safe, } 2 \\
=\text { somewhat safe, } 3=\text { very safe }\end{array}$ & 314 & & 2.8 & 0.4 & 1 & 3 \\
\hline $\begin{array}{l}\text { M-iva: freedom of movement-travelling } \\
\text { within the village }\end{array}$ & $\begin{array}{c}1=\text { not at all safe, } 2=\text { somewhat unsafe, } \\
3=\text { somewhat safe, } 4=\text { very safe }\end{array}$ & 312 & & 3.2 & 0.8 & 1 & 4 \\
\hline $\begin{array}{c}\text { M-ivb: freedom of movement-travelling } \\
\text { within the district }\end{array}$ & $\begin{array}{c}1=\text { not at all safe, } 2=\text { somewhat unsafe, } \\
3=\text { somewhat safe, } 4=\text { very safe }\end{array}$ & 314 & & 3.0 & 0.8 & 1 & 4 \\
\hline $\begin{array}{l}\text { M-ivc: freedom of movement-travelling } \\
\text { within the province }\end{array}$ & $\begin{array}{c}1=\text { not at all safe, } 2=\text { somewhat unsafe, } \\
3=\text { somewhat safe, } 4=\text { very safe }\end{array}$ & 313 & & 2.9 & 0.8 & 1 & 4 \\
\hline $\begin{array}{l}\text { M-vi: confidence do you have in the police's } \\
\text { ability to maintain security in the area }\end{array}$ & $\begin{array}{c}1=\text { not much confidence, or no } \\
\text { confidence at all, } 2 \text { = some confidence, } 3 \\
=\text { a lot of confidence }\end{array}$ & 314 & & 2.7 & 0.7 & 1 & 3 \\
\hline $\begin{array}{l}\text { M-vii: the overall performance of the ANP } \\
\text { in the area }\end{array}$ & $(1=$ poor, 2 = fair, 3 = good, $4=$ excellent $)$ & 313 & & 3.1 & 0.8 & 1 & 4 \\
\hline
\end{tabular}

a Poststratification weighing for the survey in Region 0 is between 1.1 and 1.2 and between 2.0 and 2.2 in Region 1.

\subsection{Perceived Police Station Accessibility}

Both the proximity and accessibility of the police station would impact not only the ability of police to effectively distribute the services, but also the population's having access to those services. Even though services and facilities are established purposely to make a considerable difference to the community, distance to services or facilities could contribute to their underuse or the estimation of their importance [65] and potential limitation for equitable access [25]. Given that neighborhoods of each study area are within $5 \mathrm{~km}$ of the police facilities, it is assumed that these neighborhoods are within their jurisdiction and that the population could optimally access the services that the police provide. The methodology for determining the accessibility of services and facilities included two measures:

1. The proximity measurements were geospatially determined by using two approaches for quantifying distance between residents and the police facilities [43] — the shortest (straight line) distance from the center of each neighborhood block $\left(S B \_i d\right)$ to the closest police facility ( $a 1$ in Table 3) and the distance from the random-walk starting point for the survey sample location to the closest police facility ( $a 2$ in Table 3 ).

2. The perceived accessibility was determined from respondents' answers to the survey questions regarding whether the police facilities are accessible (P7a, $P 7 b$, and $P 7 c$ in Table 3$)$. 


\subsection{Perceived Police-Community Relations}

A police force that is known to be fair and responsive is more effective than one that is not $[66,67]$; fairness and responsiveness are recognized to promote a positive identity of trustworthiness and effectiveness [37,39-42,68]. Sunshine and Tyler [62] emphasized that legitimacy had a strong influence on the public's reactions to the police; the key antecedent of legitimacy included the fairness of the procedures used by the police. The perceived impact of the facilities on police-community relations, per the survey data $(P 10, P 16, P 18 a$, and P20a in Table 3), included responses on the level of trust, confidence, and police participation in the neighborhood. Community events that the ANP staff participate in, such as social gatherings, community development, local programs, Islamic prayers and festivals in mosques, funeral ceremonies, wedding, New Year celebration, etc., promote interactions that build relationships with the community [43].

\subsection{Perceived Neighborhood Improvements}

This study presumed that the community would perceive greater improvements if people live in a safer area than in a less safe area. As such, progress was examined to determine whether the police facilities have provided a significant impact on the local population through creating job opportunities, improving security, or better fulfilling basic human needs $[2,16,17]$. Moreover, police facilities are rooted in the community as anchor institutions with institutional resources for residents to rely on for local security. Anchor institutions could potentially bring crucial and measurable benefits to communities. The perceived improvements included the police facilities as an institutional infrastructure for providing income, enticing new business, promoting patriotism, establishing local and national identity, and boosting population changes (P13b, P13c, P13d, P13e, P13f, P13g, P13h, and $P 12$ in Table 3). These perceived improvements are indicators of the economic or social impacts towards stability, security, and resiliency due to the police station in the neighborhoods.

\section{Methods: Analytic Models}

Hierarchical models have been used to understand crimes in neighborhoods with different ethnic compositions [69], the relationship between quality of life and satisfaction with the police [64], violence associations in concentrated unstable neighborhoods [70], as well as homicide rate and confidence in the police [71]. To account for the clustering and nonlinearity of the perception data, this study used a hierarchical model approach, allowing analysis of nested data and taking account the variability associated with each level of the hierarchy [72-77]. The HGLM analyses represented the probability at two levels: (1) a level-1 model described the effects of individual response variables and (2) a level-2 model described the random or varying effects of response variables across neighborhoods. HGLMs with a multinomial distribution and cumulative logit link functions were assigned to compute the likelihood of a response (on sense of safety and important factors the facility contributed to the community) with polytomous outcomes for estimating the pattern of change for categorical and nonnormally distributed response variables, including proportions [72,78,79].

Four categories of safety perception measures (Tables 2, 4 and 5) were modeled individually in HGLM, each as a dependent variable, along with the responses that were nested within the neighborhood block $\left(S B \_i d\right)$ in two study areas (SA\#2 $=0$ and SA\#1 $\left.=1\right)$. Category A examined Afghans' feeling of safety because of having police facilities at their present locations. Category B modeled people's perception that their neighborhood is considered safe because of having the police facilities in their area. Category $C$ evaluated previous perceived security in the neighborhood by using the TAF 2012 survey. Category D quantified people's general perception of safety by using the selected MPICE survey taken in 2012. Each of the dependent variable's intercepts described an incremental change in category, indicating each intercept as a one-unit change of probability in the "disagree", "neutral", or "agree" category. These four perception of safety models nested in the neighborhood 
blocks were respectively formulated into two parts to capture the outcome of each dependent variable and its collective association with independent variables for each level in the hierarchy.

\subsection{The Unconditional (U) Model}

The first part consisted of an unconditional (U) model without any predictors or independent variables to estimate the random effect of the intercept between neighborhood blocks, designated as models $\mathrm{U}-\mathrm{A}, \mathrm{U}-\mathrm{B}, \mathrm{U}-\mathrm{C}$, and $\mathrm{U}-\mathrm{D}$ for each level in the hierarchy.

\subsubsection{Model U, Level-1}

The variation in probability of people's perception of safety within the neighborhood was expressed as

$$
\begin{gathered}
\eta_{1 i j}=\log \left(\frac{P\left(R_{i j} \leq 1\right)}{1-P\left(R_{i j} \leq 1\right)}\right)=\beta_{0 j}+\beta_{1 j} X_{i j} \\
\eta_{2 i j}=\log \left(\frac{P\left(R_{i j} \leq 2\right)}{1-P\left(R_{i j} \leq 2\right)}\right)=\beta_{0 j}+\beta_{2 j} X_{\mathrm{ij}}+\delta_{j} \\
\eta_{3 i j}=\log \left(\frac{P\left(R_{i j} \leq 3\right)}{1-P\left(R_{i j} \leq 3\right)}\right)=\beta_{0 j}+\beta_{3 j} X_{i j}+\delta_{j} .
\end{gathered}
$$

Here, the expressions for the multiple logits $\left(\eta_{1 i j}, \eta_{2 i j}\right.$, and $\left.\eta_{3 i j}\right)$ modeled the corresponding $\log$-odds (probability, $P$ ) for each response, $R$, category (i.e., $1=$ disagree, $2=$ neutral, and $3=$ agree). More specifically, $\eta_{1 i j}$ assigned the average log-odds of the lowest response (i.e., $1=$ disagree) for respondents' sense or level of safety, $i$, in neighborhood j. $P\left(R_{i j} \leq 1\right)$ is designated as the probability of disagreeing, and $1-P\left(R_{i j} \leq 1\right)$ is the overall probability of not disagreeing (or responses other than disagree). $X_{i j}$ is a response-level predictor for respondents' sense of safety, $i$, in neighborhood $j$. The multiple logits can be expressed in terms of intercept $\beta_{0 j}$ and the corresponding slopes $\left(\beta_{1 j}, \beta_{2 j}\right.$, and $\beta_{3 j}$ ) for each response category, with an error term $(\delta)$ fixed across in neighborhood $j$.

\subsubsection{Model U, Level-2}

The expression for intercept $\beta_{0 j}$ accounted for the mean log-odds of sense of safety in neighborhood $j$ :

$$
\beta_{0 j}=\gamma_{00}+\gamma_{01} W_{j}+u_{0 j}, \beta_{0 j}=\gamma_{10}, \ldots \delta_{j}=\delta
$$

Here, Level- 2 was represented with the intercept $\gamma_{00}$ for the log-odds of the sense of safety response across the neighborhoods, the associated slope $\gamma_{01}$ for the predictor, and the error term, $u_{0 j}$, representing a unique effect associated within the neighborhood block. From the model's estimation of the random effect of the intercept, the probability and variability of the Level-1 predictors and the Level-2 outcome were quantified in terms of probability predictors $(P P)$ and an intraclass correlation coefficient (ICC) as follows

$$
\begin{gathered}
P P_{\text {response } 1}=\phi_{i j}=\frac{e^{\eta_{1 i j}}}{1+e^{\eta_{1 i j}}} \\
I_{C C_{S B}}=\frac{\tau_{S B}}{3.29+\tau_{S B}}
\end{gathered}
$$

The ICC value (Equation (4)) was used to estimate how much variation in the outcome exists for Level-2 (in this case, the neighborhood blocks) using the covariance parameter estimates, $\tau_{S B}$, with a variance of $3.29[72,77,80]$.

\subsection{Random Intercept (RI) Model}

The probabilities of individual-level responses of people's perception of safety were collectively modeled to quantify the multivariate association with independent variables, such as perceived neighborhood improvements, police performance, and demographics data across the neighborhoods. To examine which predictors have a significant relationship with the response or dependent variable, 
the model began by listing all the independent variables and manually removing the individually variables with no probability of significance $(p>0.1)$ until a parsimonious model was achieved based on the best statistical model fit [72,78]. The RI models are denoted as RI-A, RI-B, RI-C, and RI-D for each level in the hierarchy.

\subsubsection{RI Model, Level-1}

To facilitate a meaningful description of the model, a parsimonious model relationship for Category RI-A outcome was used in this case to describe the perceived level of safety, $i$, in neighborhood block $j$. Equation (1) for $\eta_{1 \mathrm{ij}}$ becomes

$$
\begin{aligned}
\eta_{1 i j} & =\gamma_{00}+\gamma_{10}(\text { Region })_{i j}+\gamma_{20}(\text { Neigborhood })_{i j} \\
& +\gamma_{30}(\text { P7a suitable location })_{i j}+\gamma_{40}(\text { P7b accesible location })_{i j} \\
& +\gamma_{50}(\text { P7c People report crime })_{i j}+\gamma_{60}(\text { P11 Rate of safety })_{i j} \\
& +\gamma_{70}(\text { P10 Trust })_{i j}+\gamma_{80}(\text { P16 Confidence })_{i j} \\
& +\gamma_{90}(\text { P13e Restablish Police })_{i j}+\gamma_{100}(\text { P13g National identity })_{i j} \\
& +\gamma_{110}(\text { P13f Promoted patriotism })_{i j}+\gamma_{120}(\text { (a2 Proximity })_{i j} \\
& +\gamma_{01} W_{j}+u_{0 j} .
\end{aligned}
$$

\subsubsection{RI Model, Level-2}

The formulation for Level-2 is similar to Equation (2). While the model allowed the common intercept, $\beta_{0 j}$, to vary across neighborhood blocks, the difference between the logits $(\delta)$ remained fixed across neighborhood blocks. The RI model appropriately accounted for clustering (lack of independence) between individuals living within the same block and ensured that the standard errors were not underestimated. Again, $\gamma_{00}$ corresponds to the log-odds of sense of safety response across the neighborhoods, with the associated slopes $\gamma_{10} \ldots \gamma_{120}$ ) for each predictor. With a similar approach to examine the other dependent variables, the best-fitting outcome of predictors for other models differed. Thus, estimating the probabilities for four perceived level of safety measures as dependent variables resulted in varying multivariate (i.e., independent variables) association with individual-level responses of people's perception of safety across the neighborhoods. The response categories and the associated multivariate slopes for each model solution are indicated by the beta coefficients, $B$, for representing the log-odds.

\section{Results}

\subsection{Police Facilities' Impact on the Perception of Safety}

In unconditional model $\mathrm{U}-\mathrm{A}$ (P7e, Table 6), the output denoted a statistical significance in the likelihood (i.e., log-odds) that perceptions of safety varied across the neighborhoods $\left(\tau_{S B}=1.47\right)$. The random effects of the respondents' feeling safer presented significance across the neighborhood blocks; the ICCSB_id of 0.31 (Table 6), suggests that $31 \%$ of the variation in respondents' perceptions of safety was due to block-level factors, and $69 \%$ was attributed to other individual-level factors. A probability (PPagree \& strongly agree) of 0.74 corresponded to respondents' agreeing that they felt safe within the neighborhood blocks (U-A, Table 6). Despite the negative values of the intercepts, the effects for disagree, neutral, and agree of people's feeling safer followed an increasing incremental change of responses. In addition, the average odds ratio of 2.57 indicated respondents' agreeing that they felt safer within the neighborhood. 
Table 6. Model outcome on neighborhood safety and police facilities' contributions to providing security.

\begin{tabular}{|c|c|c|c|c|c|c|c|c|c|c|c|c|}
\hline \multirow{3}{*}{$\begin{array}{c}\text { Dependent Variables } \\
\text { Model Descriptors } \\
\text { Fixed Effects } \\
\end{array}$} & \multicolumn{6}{|c|}{ P7e: People Are Now Feeling Safer } & \multicolumn{6}{|c|}{ P13a: Security to the Community } \\
\hline & \multicolumn{3}{|c|}{$\mathrm{U}-\mathrm{A}$} & \multicolumn{3}{|c|}{$\mathbf{R I}-\mathbf{A}$} & \multicolumn{3}{|c|}{$\mathrm{U}-\mathbf{B}$} & \multicolumn{3}{|c|}{ RI-B } \\
\hline & $B$ & OR & SE & $B$ & OR & SE & $B$ & OR & SE & $B$ & OR & SE \\
\hline$\gamma_{00}=$ Intercept, Disagree & -3.10 & 0.04 & $0.40^{\mathrm{a}}$ & -9.12 & 0 & $0.84^{\mathrm{a}}$ & & & & & & \\
\hline$\gamma_{01}=$ Intercept, Neutral & -1.25 & 0.29 & $0.33^{\mathrm{a}}$ & -6.84 & 0 & $0.74^{\mathrm{a}}$ & -2.70 & 0.07 & $0.40^{\mathrm{a}}$ & -9.84 & 0 & $1.44^{\mathrm{a}}$ \\
\hline$\gamma_{02}=$ Intercept, Agree & 0.95 & 2.57 & $0.32^{\mathrm{a}}$ & -4.05 & 0.02 & $0.61^{\mathrm{a}}$ & -0.09 & 0.91 & 0.34 & -5.89 & 0 & $1.28^{\mathrm{a}}$ \\
\hline Age & & & & & & & & & & 0.03 & 1.03 & $0.02^{b}$ \\
\hline Region & & & & -0.67 & 0.44 & $0.33^{\mathrm{a}}$ & & & & & & \\
\hline a2: Proximity ${ }^{\mathrm{c}}$ & & & & 0.66 & 1.93 & $0.20^{\mathrm{a}}$ & & & & 0.64 & 1.90 & $0.39^{b}$ \\
\hline P7a: Suitable location & & & & & & & & & & 0.41 & 1.51 & $0.19^{a}$ \\
\hline P7b: Accessible location & & & & 0.93 & 2.53 & $0.21^{\mathrm{a}}$ & & & & & & \\
\hline P7c: People report crime & & & & 0.41 & 1.50 & $0.19^{\mathrm{a}}$ & & & & & & \\
\hline P11: Safety compare to past & & & & -0.40 & 0.67 & $0.19^{\mathrm{a}}$ & & & & & & \\
\hline P10: Trust & & & & 0.85 & 2.34 & $0.29^{\mathrm{a}}$ & & & & & & \\
\hline P16: Confidence & & & & 0.29 & 1.34 & $0.16^{\mathrm{b}}$ & & & & & & \\
\hline P13e: Reestablish police & & & & -0.42 & 0.66 & $0.21^{\mathrm{a}}$ & & & & & & \\
\hline P13g: National identity & & & & 0.58 & 1.79 & $0.22^{\mathrm{a}}$ & & & & & & \\
\hline P13f: Promoted patriotism & & & & 0.41 & 1.51 & $0.24^{\mathrm{b}}$ & & & & 0.73 & 2.06 & $0.25^{\mathrm{a}}$ \\
\hline P13d: Provided growth & & & & & & & & & & 0.72 & 2.05 & $0.26^{\mathrm{a}}$ \\
\hline P13b: Provided income & & & & & & & & & & 0.90 & 2.47 & $0.23^{\mathrm{a}}$ \\
\hline P17: Adequate security & & & & & & & & & & -1.26 & 0.28 & $0.40^{\mathrm{a}}$ \\
\hline P18a: Local involved & & & & & & & & & & -0.76 & 0.38 & $0.38^{\mathrm{a}}$ \\
\hline \multicolumn{13}{|c|}{ Covariance Estimates } \\
\hline$\tau_{S B}=$ Intercept, $S B \_i d$ & 1.47 & 4.33 & $0.63^{\mathrm{a}}$ & 0.04 & 1.04 & 0.16 & 1.71 & 5.53 & $0.83^{\mathrm{a}}$ & 1.15 & 3.17 & $0.65^{\mathrm{a}}$ \\
\hline \multicolumn{13}{|c|}{ Probability Variations } \\
\hline$I C C_{S B \_i d}$ & & 0.31 & & & & & & 0.34 & & & & \\
\hline$P P_{\text {disagree }}$ & & 0.04 & & & & & & 0.06 & & & & \\
\hline$P P_{\text {neutral }}$ & & 0.22 & & & & & & 0.48 & & & & \\
\hline$P P_{\text {agree \& strongly agree }}$ & & 0.74 & & & & & & 0.46 & & & & \\
\hline Model Fit, -2 Log Likelihood & & 516.59 & & & 413.37 & & & 393.26 & & & 278.61 & \\
\hline $\begin{array}{l}\mathrm{U} \text { means unconditiona } \\
\text { are now feeling safer }(\mathrm{I} \\
\text { (Primary survey data) } \\
p<0.10 \text { value. }{ }^{\text {a }} p<0 \\
\text { proximity measureme } \\
\text { the distance from star } \\
\text { police facility-have sta }\end{array}$ & $\begin{array}{l}\text { model } \\
\text { rimary s } \\
\text { RI (Rar } \\
05{ }^{\text {b } p} \\
\text { ts-dista } \\
\text { ing poin }\end{array}$ & $\begin{array}{l}\text { of rand } \\
\text { survey } \\
\text { ndom I } \\
<0.10 \text {; } \\
\text { ance fro } \\
\text { nt for e }\end{array}$ & $\begin{array}{l}\text { om effe } \\
\text { lata) an } \\
\text { ntercep } \\
B=\text { bet } \\
m \text { the } c \\
\text { ch nei }\end{array}$ & $\begin{array}{l}\text { ts for th } \\
U-B \text { is } \\
\text { model } \\
\text { coeffici } \\
\text { osest po } \\
\text { hborhoo }\end{array}$ & $\begin{array}{l}\text { e interc } \\
\text { the un } \\
\text { with i } \\
\text { ents; } C \\
\text { lice fac }\end{array}$ & $\begin{array}{l}\text { epts; U } \\
\text { conditic } \\
\text { ndepen } \\
\text { dd Rat } \\
\text { ility to }\end{array}$ & $\begin{array}{l}\text { A is th } \\
\text { hal mod } \\
\text { lent va } \\
\text { (OR) } \\
\text { e repr }\end{array}$ & $\begin{array}{l}\text { uncon } \\
\text { el for } P \\
\text { iables } \\
=e^{B} ; \mathrm{S} \\
\text { esentati }\end{array}$ & $\begin{array}{l}\text { ditione } \\
3 a \text { : Se } \\
\text { laving } \\
=\text { sta } \\
\text { ye resp }\end{array}$ & $\begin{array}{l}\text { model } \\
\text { rity to tl } \\
\text { atistica } \\
\text { ard err } \\
\text { hdents' }\end{array}$ & $\begin{array}{l}P 7 e: P e \\
\text { comm } \\
\text { ignific } \\
{ }^{c} \text { Botl } \\
\text { cations }\end{array}$ & \\
\hline
\end{tabular}

Similarly, a statistical significance of likelihood for model U-B (P13a, Table 6) was found in the log-odds of perceived neighborhood security by having the ANP facility for providing security to the community $\tau_{S B}=1.71$ ). Neighborhood as a random variable produced an odds ratio of 5.33 on perceived neighborhood security by having the ANP facilities within the neighborhoods. The random effects of the respondents' perception of security in their neighborhood by having the ANP facility for providing security to the community showed significance across the neighborhood blocks. The ICCSB_id of 0.34 (model U-B, Table 6), denotes that $34 \%$ of the variation was due to block-level factors for respondents' perceptions that their neighborhood was secure with the presence of the ANP facility, and $66 \%$ was attributed to other individual-level factors.

The collective models RI-A and RI-B (Table 6) included multilevel effects with best-fit predictors of residents' likelihood of feeling safe and the perceived security outcomes between neighborhood blocks. The log-odds of peoples' feeling safer living their community showed the response variable incrementally increasing from disagree to agree responses (model RI-A). People's present feeling of safety was positively related to the proximity of the closest police facility to the representative respondents' locations $(p<0.001, B=0.66)$, perceived accessibility of the police facilities $(p<0.0001$, $B=0.93)$, and knowing that people have been reporting crimes $(p=0.04, B=0.41)$. Both proximity measurements ( $a 1$ and $a 2$, Table 3 ) showed statistical significance in the model. In addition, people's feeling safer positively correlated to their existing trust $(p=0.004, B=0.85)$ and confidence $(p=0.07, B$ $=0.29)$ in the police. Moreover, people's present feeling of safety was positively associated with the facilities' promoting patriotism $(p=0.08, B=0.41)$ and national identity $(p=0.008, B=0.58)$ for their 
community. A one-unit change in the perception of the police facility's accessibility corresponded to 2.53 times greater odds of people's feeling safer; likewise, a one-unit change in having trust in the police developed twice greater odds that people felt safe. The model results emphasized people's perception that they felt safe because of trust in the local police force to protect people's personal safety and confidence in the police resulting from police interaction for enforcing the law and maintaining public order, which would boost resilience $[27,30,34-38]$ in the community. Trust builds up mutual confidence in the community [81] and an alliance between police and residents [68] to create a safe environment. Overall, people's present feeling of safety was negatively associated with the region, indicating that people felt less safe in SA\#1 than in SA\#2, which was opposite to the initial assumption of the study. Lastly, the results denoted that people's perception of their safety in the past showed no association to the present feeling of safety, which probably meant that people cared more about their present level of safety than what happened in the past.

Similarly, the log-odds shown for the RI-B model showed the response variables incrementally increasing from neutral to agree for perceived neighborhood security by having the ANP facility. The two study areas (regions), neighborhood types (urban versus suburban), population density, and respondents' gender were unrelated to perceived neighborhood security, which potentially signified uniformity of peoples' views that their neighborhood was secured by having the ANP facilities. The positive likelihood of people perceiving that the ANP facility provided security to the community (RI-B, Table 6) was associated with respondents' ages, the proximity, and having the police facilities suitably located to residents. Police facilities' impact on the perception of safety was also positively associated with the notion that having the facilities promotes patriotism, improvements, and income and jobs for the residents. A one-unit change in perceived contribution by generating income or jobs for the community (P13b) corresponded to 2.47 times greater odds that people perceived security in their neighborhood. The police facilities can leverage as catalysts for social capital and growth $[2,25,39-41]$, for creating stable and resilient communities [2,18-21], as well as building sustainable societies [22-25].

\subsection{Previous Perception of Security}

Table 7 shows the parameter estimates from unconditional models ( $U-C$ and $U-D)$, and the collective outcomes (RI-C and RI-D) of the security conditions in 2012 from TAF and MPICE datasets. Probability $\left(P P_{\text {good }}\right)$ of 0.90 and 0.80 corresponded to respondents' rating the security situation as very good across their neighborhood blocks for $\mathrm{U}-\mathrm{C}$ and $\mathrm{U}-\mathrm{D}$ models (Table 7), respectively. People's view of the security conditions in their neighborhood in the 2012 TAF indicated a positive association with the respondents' education level and negative association with region, neighborhood type, perception of security conditions in the districts, and perception that having the ANP was helping to improve security. Similar to model RI-A, people's sense of safety was higher in SA\#2 than in SA\#1, and the respondents in urban areas felt less safe than in villages. People's perception of the security conditions in their neighborhood in 2012 from MPICE data was positively associated with the respondents' marital status and their perception of freedom to travel within their village. Overall, from these two datasets, people's perception of the security of their neighborhoods showed no association with age, ethnicity, education, and gender. This study reinforced the fundamental psychological and socioeconomic theories for human needs that security is imperative for social well-being $[16,17,25,56,81]$, regardless of sociodemographic background. 
Table 7. Model outcome on the Perceived Security Situation in Neighborhoods in 2012.

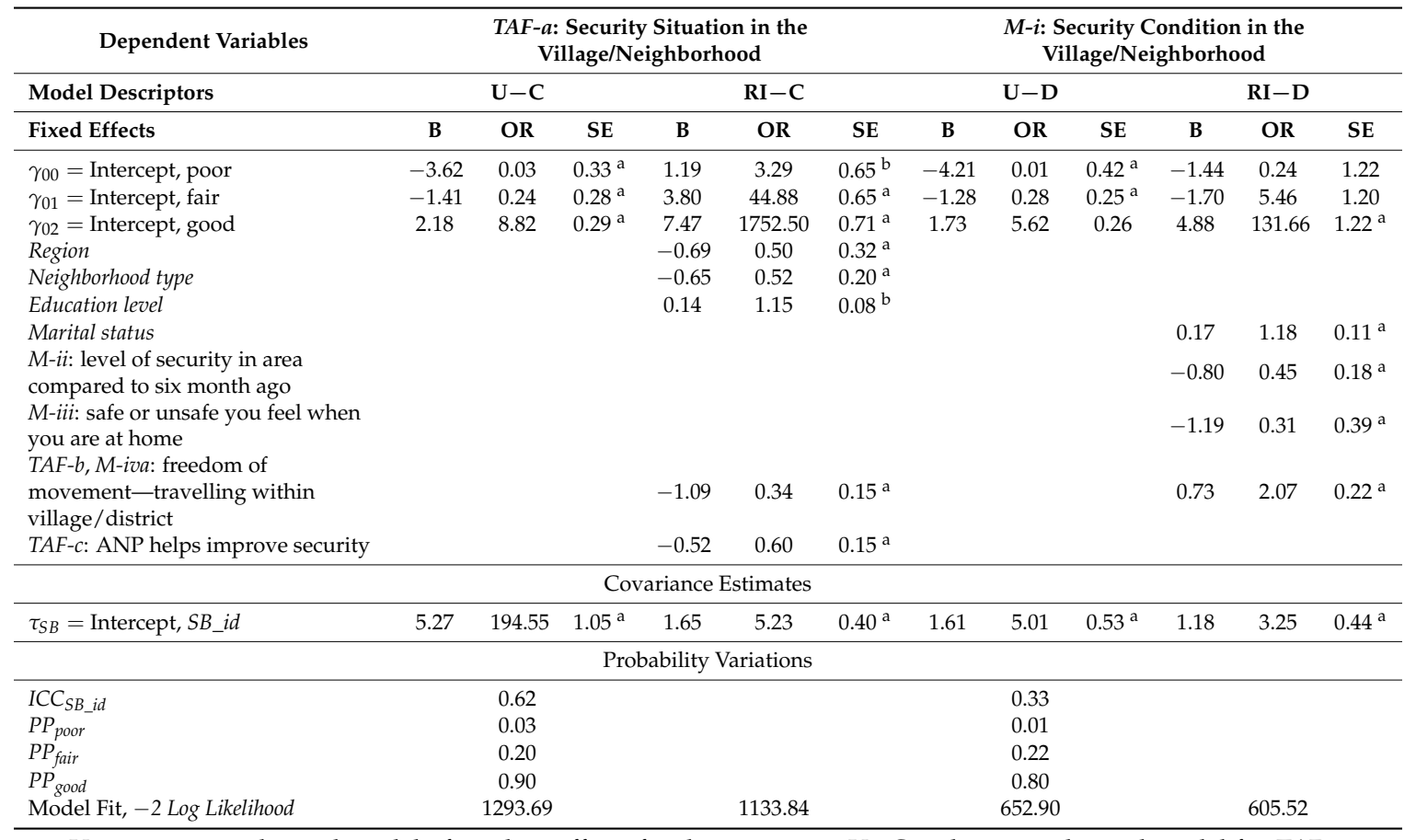

$\mathrm{U}$ means unconditional model of random effects for the intercepts; $\mathrm{U}-\mathrm{C}$ is the unconditional model for TAF- $a$ : Security condition in the village (Asia Foundation 2012 data) and U-D is the unconditional model for M- $i$ : Security condition in the village (MPICE 2012 data). RI (Random Intercept) model with independent variables having statistical significance, $p<0.10$ value. ${ }^{\mathrm{a}} p<0.05 ;{ }^{\mathrm{b}} p<0.10 ; B=$ beta coefficients; Odd Ratio $(\mathrm{OR})=e^{B}$; $\mathrm{SE}=$ standard error.

\section{Discussion}

First, this study initially hypothesized that, overall, SA\#1 was perceived as safer than SA\#2, based on an individual-level comparison of the existing people's perception of safety between the two study areas of Afghanistan [43]. The multilevel model results actually indicated the opposite. People's perception that the security situation in their neighborhood is progressing (TAF 2012 data) was negatively associated with the two study areas and neighborhood type, independent of age, gender, ethnicity, and marital status. Being away from a bustling environment, Afghans in villages perceived themselves as safer than in urban areas. Having the ANP facilities at the present locations, people's present feeling of safety based on the September 2016 and March 2017 survey was higher in SA\#2 than SA\#1. Among the sociodemographic variables, age correlated significantly with people's perception that their neighborhood is safe because of having the police facilities; older Afghan respondents perceived that their neighborhood was safer than younger ones did. This study confirmed with previous findings on the effects of age and gender on police confidence-overall, older people had higher confidence in the police and perception between genders showed a marginal significance with police confidence $[61,71,82-84]$. This seemed to imply that older Afghans have higher tolerances of insecurity because they have experienced security disruptions and chaos for many decades compared to younger Afghans, or older residents could be more homebound and less impacted by insecurity. People with more education perceived themselves as safer than people with less education, according the regional perception of safety (TAF 2012 data). It appeared that educated Afghans may have other ways or connections to make themselves safe, while less educated Afghans seemed vulnerable and defenseless, or that educated Afghans are more informed about and have a broader perspective of the relative local insecurity related to elsewhere in the region.

Conceivably, having police stations placed in accessible locations would enable residents to obtain services and would allow police to allocate civil services and exert collective safety efforts for the community. The distance to services and facilities makes a difference to community engagement. The 
farther the services or facilities are from the recipients, the greater the likelihood of their underuse or underestimation of their importance [65], and they would potentially provide less of an impact to the community [25]. The model provided distinct results on the influence of the police facilities' location on perceived measures of safety. First, the proximity of the respondents to the closest police station showed association to perceived measures of safety in a counterintuitive way. The analysis indicated that the farther the respondents' houses were from the police station, the safer they felt. This is assumed to be because ANP facilities are vulnerable as potential targets for insurgency attacks [43], which has impacted the safety of the nearby neighborhood. This is an intricate issue that dampened any resiliency progress on human security. Secondly, people's present feeling of safety because of having police facilities was positively related to the perceived accessibility of the police facilities' location and knowing that people have been reporting crimes. Having the police facility accessibly located for local citizens more than doubles the odds of people's feeling safer, regardless of distance. While nearby respondents are able to walk to the police station, distant Afghans have other means (either by calling the police station or using a vehicle to get to the station) for reporting a crime or incident to the police [43]. The results reinforced the fact that residents at a peripheral distance to the police station seemed safer than those closer to the police station. Distant residents could still purposely access and acquire the police services for safety needs with minimal exposure to external hazards.

In challenging environments where safety progress is constantly disrupted by insurgency attacks, corruption or by other external civil protection interference, trustworthiness and effectiveness of the Afghan police are impeded by the dynamic security. Social interaction between the ANP and the community have influenced peoples' perceived safety based on the police performance and the presence of trust and confidence in the police. Culturally, Afghan communities have strong group solidarity and kinship, which contribute positive benefits to the group and for social reforms $[1,55,85]$. Considering their ethnic differences, unity, and having an undivided country seems to be more important to most Afghans than their ethnic distinction [1,55]. Thus, a certain level of generalized trust exists to create such unity among the Afghans. The model highlighted that residents' trust in the police doubles the odds of their feeling safe. Likewise, people's confidence in the police as a result of police interaction provided greater odds of people's feeling safer. Given the challenges in creating effective, accountable, and rights-respecting police forces [44-46], polling data acknowledged that overall the Afghan police are considered honest and fair $[57,58]$. The presence of generalized trust has been known to increase social well-being, resulting in societal solidarity, boost mutual confidence, and build the institution's proficiency for improvement of services [81]. Collectively, the security of people (in the form of liberty and rule of law) depends on a sense of fairness by enforcing peace and order, resulting in social trust in return [9,53-56]. Likewise, those who trust generally also trust specific institutions at a higher rate than those who do not have generalized trust, but the reverse does not necessarily hold. That is, those who trust a specific institution may not abstract that trust more generally.

\section{Summary and Conclusions}

This study was the first of its kind to use a multilevel model approach to assess the relationships of residents' perception of security and other social well-being factors of sustainability that come from having the police facilities within Afghan neighborhoods. The four selected dependent variables were modeled with two unconditional settings: (1) only random effects for the intercept without predictors and (2) collective associations of predictors with the best-fit responses and effects. The models included perception of safety: people's present feeling of safety because of having police facilities at their present locations (September 2016 and March 2017 datasets), people's perception that their neighborhood is safe because of having the police facilities, and people's perception of safety based on the 2012 TAF and MPICE survey data. These four measures of safety provided various contexts of security conditions (a community evaluation of safety influenced by having the police facilities and a generalized regional perception of security taken at different time). The collective model examined the association of the perception of safety due to the police facilities' impact with 
other variables such as police facility accessibility, police-community relations (through trust and confidence), perceived community improvement, and growth in these neighborhoods. This study was the first of its kind to assess the impact of police facilities on the perception of safety within Afghan neighborhoods. The results suggested that the USG investment in building police facilities sustainably contributed to the safety progress, particularly in the less safe neighborhoods.

Sociodemographic variables provided a cross-sectional understanding of the relevance of perceived safety. Gender and ethnicity showed no association to all the measures of people's perception of safety, which meant that security equally matters for the well-being of all social groups in both neighborhoods. However, as the results suggested that older Afghan respondents perceived that their neighborhood was safer than younger ones did, it is critical to focus the attention of safety needs and to use policing programs designed particularly for the younger generations and vulnerable populations; this would yield positive effects for influencing long-term stability for their future well-being. Moreover, future study for enduring security should include potential confounding factors, such as the influences of drugs and crime due to opium production [86], the effects of accessibility to services, and police relations with the community in light of disruptions by militants.

In conclusion, people's perception of security differed in time and space in these Afghan communities based on 2012 versus September 2016 and March 2017 datasets. The addition of police infrastructure as an anchor institution in the community seemed to support security, resilience, and growth, considering the challenging environment. By and large, the mission objectives for constructing the police infrastructure by the USG and coalition partners in these two study areas have shown some sustainability effectiveness, and are instrumental for progressively fulfilling public safety needs, for generating growing levels of self-reliance [16] and social well-being [17], and for increasing sovereignty or governing authority for the society [11,54]. Moreover, the Chief Executive of Afghanistan, Dr. Abdullah [87], optimistically indicated in his interview that "Afghans on the ground are making their best effort" to find their way out of war and to restore security.

Author Contributions: Conceptualization and Framework, R.A., K.G., S.A., C.C., and C.G.; Methodology (analytic models), R.A., S.A., and C.C.; Formal Analysis, R.A.; Investigation, R.A.; Data Curation, R.A. and S.A.; Writing-Original Draft Preparation, R.A.; Writing-Review and Editing, K.G., S.A., C.C., C.G., and E.D.; Funding Acquisition, R.A. and K.G.

Funding: The survey collection work for this study was funded by both the University of New Hampshire and the U.S. Army Engineer Research and Development Center (ERDC). The research described and the resulting analyses presented herein were funded, managed, and executed under the U.S. Army ERDC Section 219 Innovative Basic and Applied Program.

Acknowledgments: The authors acknowledge the support Stacey Frank and Veronica Gardner, D3 Systems Inc., for coordinating with their Afghan affiliates at ACSOR Surveys and for bringing the survey sampling efforts to fruition, which was a big milestone for the study. The police questionnaires were reviewed by Fire Marshal (former Detective) Anthony Booth, Sergeant Roy Holland, and Officer Courtland Smith; all three served the Vermont National Guard and worked with the Afghan police force during their tours in Afghanistan. Editorial input was provided by Emily Moynihan of ERDC-CRREL.

Conflicts of Interest: The authors declare no conflicts of interest. The funders had no role in the design of the study; in the collection, analyses, or interpretation of data; in the writing of the manuscript, or in the decision to publish the results.

\section{References}

1. Barfield, T. Afghanistan: A Cultural and Political History; Princeton University Press: Princeton, NJ, USA, 2010.

2. Collier, P. State-building: Job creation, investment promotion and the provision of basic services. Prism 2011, 2, 17-30.

3. DA (Department of the Army). Stability Operations; Field Manual 3-07; Department of the Army: Washington, DC, USA, 2008. 
4. DOD (Department of Defense). Military Support for Stability, Security, Transition, and Reconstruction (SSTR) Operations; DoDD 3000.05; Department of Defense: Washington, DC, USA, 2005. Available online: http: / policy.defense.gov/portals/11/Documents / solic/DoDD\%203000.05\%20SSTR\%20(SIGNED) \%2028NOV05.pdf (accessed on 10 January 2011).

5. DOD. Instruction: Stability Operations; DoDI 3000.05; Department of Defense: Washington, DC, USA, 2009.

6. DOD. Stability Operations; Joint Publication 3-07; Department of Defense: Washington, DC, USA, 2011.

7. DOD. Security Cooperation; Joint Publication 3-20; Department of Defense: Washington, DC, USA, 2017. Available online: https://www.jcs.mil/Portals/36/Documents/Doctrine/pubs/jp3_20_20172305.pdf (accessed on 12 January 2011).

8. Fukuyama, F. Nation-Building: Beyond Afghanistan and Iraq; Johns Hopkins University Press: Baltimore, MD, USA, 2008.

9. Kaufmann, G. Stability Operations and State-Building: Continuities and Contingencies; U.S. Army War College, Strategic Studies Institute: Carlisle, PA, USA, 2008.

10. Shin, D.W. Narrowing the Gap: DOD and Stability Operations. Mil. Rev. 2009, 89, 23. Available online: http:/ / www.armyupress.army.mil/Portals/7/military-review/Archives/English/MilitaryReview_ 20090430_art006.pdf (accessed on 6 June 2016).

11. Ghani, A.; Lockhart, C. Fixing Failed States: A Framework for Rebuilding a Fractured World; Oxford University Press: New York City, NY, USA, 2008.

12. Cordesman, A.H. Afghanistan at Transition: The Lessons of the Longest War; Center for Strategic and International Studies: New York City, NY, USA, 2015.

13. SIGAR (Special Inspector General for Afghanistan Reconstruction). Quarterly Report to the United States Congress; Office of the Special Inspector General for Afghanistan Reconstruction: Arlington, VA, USA, 2017. Available online: https:/ / www.sigar.mil/pdf/quarterlyreports/2017-04-30qr.pdf (accessed on 24 June 2017).

14. Buzan, B.; Wæver, O.; De Wilde, J. Security: A New Framework for Analysis; Lynne Rienner Publishers: London, UK, 1998.

15. Mandel, R. What are we protecting? Armed Forces Soc. 1996, 22, 335-355. [CrossRef]

16. Max-Neef, M.A. Development and human needs. In Real Life Economics: Understanding Wealth Creation; Ekins, P., Max-Neef, M.A., Eds.; Routledge: London, UK, 1992; pp. 197-214.

17. Maslow, A.H. A Theory of human motivation. Psychol. Rev. 1943, 50, 370-396. [CrossRef]

18. Armitage, D.; Bene, C.; Charles, T.; Johnson, D.; Allison, E. The interplay of wellbeing and resilience in applying a social-ecological perspective. Ecol. Soc. 2012, 17, 15. Available online: http://dx.doi.org/10.5751/ ES-04940-170415 (accessed on 19 May 2015). [CrossRef]

19. Davoudi, S. Resilience: A bridging concept or a dead end? 'Reframing' resilience: Challenges for planning theory and practice. Plan. Theory Pract. 2012, 13, 299-333. [CrossRef]

20. Stokols, D.; Perez Lejano, R.; Hipp, J. Enhancing the resilience of human-environment systems: A social-ecological perspective. Ecol. Soc. 2013, 18, 7. Available online: http://dx.doi.org/10.5751/ES05301-180107 (accessed on 19 May 2015). [CrossRef]

21. Tumlin, J. Sustainable Transportation Planning: Tools for Creating Vibrant, Healthy, and Resilient Communities; Wiley and Sons: Hoboken, NJ, USA, 2012.

22. United Nations. Goal 11: Make Cities Inclusive, Safe, Resilient and Sustainable; The United Nations: New York City, NY, USA, 2012. Available online: http:/ / www.un.org/sustainabledevelopment/cities/ (accessed on 4 July 2016).

23. Harris, J.M. Basic principles of sustainable development. In Dimensions of Sustainable Development: Encyclopedia of Life Support Systems; Bawa, K.S., Seidler, R., Eds.; United Nations Educational, Scientific and Cultural Organization, Eolss Publishers Co. Ltd.: Oxford, UK, 2009; pp. 21-40.

24. Shirazi, M.R.; Keivani, R. Urban Social Sustainability: Theory, Policy and Practice; Routledge: New York, NY, USA, 2019; pp. 1-10.

25. Dempsey, N.; Bramley, G.; Power, S.; Brown, C. The social dimension of sustainable development: Defining urban social sustainability. Sustain. Dev. 2011, 19, 289-300. [CrossRef]

26. Aldrich, D.P. The power of people: Social capital's role in recovery from the 1995 Kobe earthquake. Nat. Hazards 2011, 56, 595-611. Available online: http:/ /link.springer.com/article/10.1007/s11069-010-9577-7 (accessed on 19 May 2015). [CrossRef] 
27. Aldrich, D.P. Building Resilience Social Capital in Post-Disaster Recovery; University of Chicago Press: Chicago, IL, USA, 2012.

28. Carpenter, S.R.; Walker, B.H.; Anderies, J.M.; Abel, N. From metaphor to measurement: Resilience of what to what? Ecosystems 2001, 4, 765-781. [CrossRef]

29. Norris, F.; Stevens, S.; Pfefferbaum, B.; Wyche, K.; Pfefferbaum, R. Community resilience as a metaphor, theory, set of capacities, and strategies for disaster readiness. Am. J. Community Psychol. 2008, 41, 127-150. [CrossRef]

30. Pisano, U. Resilience and Sustainable Development: Theory of Resilience, Systems Thinking and Adaptive Governance; ESDN Quarterly Report No. 26; European Sustainable Development Network (ESDN) Office, Research Institute for Managing Sustainability, Vienna University of Economics and Business: Vienna, Austria, 2012.

31. Galster, G.; Cutsinger, J.; Lim, U. Are Neighborhoods Self-Stabilizing? Exploring Endogeneous Dynamics. Urban Stud. 2007, 44, 167-185. [CrossRef]

32. Azarbaijani-Moghaddam, S.; Wardak, M.; Zaman, I.; Taylor, A. Afghan Hearts, Afghan Minds: Exploring Afghan Perceptions of Civil-Military Relations; British and Irish Agencies Afghanistan Group: London, UK, 2008.

33. Marquis, J.P.; Moroney, J.D.P.; Beck, J.; Eaton, D.; Hiromoto, S.; Howell, D.R.; Lewis, J.; Lynch, C.; Neumann, M.J.; Thurston, C.Q. Developing an Army Strategy for Building Partner Capacity for Stability Operations; RAND Corporation: Santa Monica, CA, USA, 2010.

34. Folke, C.; Carpenter, S.; Walker, B.; Scheffer, M.; Chapin, T.; Rockström, J. Resilience thinking: Integrating resilience, adaptability and transformability. Ecol. Soc. 2010, 15, 352-387. [CrossRef]

35. Lebel, L.; Anderies, J.; Campbell, B.; Folke, C.; Hatfield-Dodds, S.; Hughes, T.; Wilson, J. Governance and the capacity to manage resilience in regional social-ecological systems. Ecol. Soc. 2006, 11, 19. [CrossRef]

36. Hatfield-Dodds, S.; Nelson, R.; Cook, D.C. Adaptive governance: An introduction and implications for public policy. In Proceedings of the 51st Annual Conference of the Australian Agricultural and Resource Economics Society, Queenstown, New Zealand, 13-16 February 2007.

37. Ledogar, R.J.; Fleming, J. Social capital and resilience: A review of concepts and selected literature relevant to aboriginal youth resilience research. Pimatisiwin A J. Aborig. Indig. Community Health 2008, 6, 25-48.

38. McCreight, R. Resilience as a goal and standard in emergency management. J. Homel. Secur. Emerg. Manag. 2010, 7, 1-7. [CrossRef]

39. Lin, N. Building a network theory of social capital. Connections 1999, 22, 28-51.

40. Lin, N. Social Capital: A Theory of Social Structure and Action; Cambridge University Press: London, UK, 2001.

41. Woolcock, M. The place of social capital in understanding social and economic outcomes. Can. J. Policy Res. 2001, 2, 11-17.

42. Putnam, R.D. Bowling alone, revisited. Responsive Community 1995, 5, 18-33.

43. Affleck, R.T. Infrastructure Impact for Human Security and Resilience: A Case Study; ERDC/CRREL TR-18-11; U.S. Army Engineer Research and Development Center: Hanover, NH, USA, 2018.

44. Murray, T. Police-building in Afghanistan: A Case study of civil security reform. Int. Peacekeeping 2007, 14, 108-126. [CrossRef]

45. Sedra, M. Security sector reform in Afghanistan: The slide towards expediency. Int. Peacekeeping 2006, 13, 94-110. [CrossRef]

46. Wilder, A.R. Cops or Robbers? The Struggle to Reform the Afghan National Police; Afghanistan Research and Evaluation Unit: Kabul, Afghanistan, 2007. Available online: http:/ / www.comw.org/warreport/fulltext/ 0707wilder.pdf $\backslash \mathrm{T} 1 \backslash$ textgreater \{\} (accessed on 20 May 2015).

47. United States Institute of Peace. Establishing the Rule of Law in Afghanistan; Special Report 117; United States Institute of Peace: Washington, DC, USA, 2004. Available online: https://www.usip.org/sites/default/files/ sr117.pdf (accessed on 21 January 2015).

48. Ewans, M. Afghanistan: A Short History of Its People and Politics; Harper Collins: New York City, NY, USA, 2002.

49. Sitigh, M.; Haqmal, M. Literacy and Adult Education in Afghanistan. PowerPoint Presentation. Asia-Pacific Cultural Center (ACCU), UNESCO forum on Education for Sustainable Development (ESD). 2010. Available online: https:/ / www.accu.or.jp/esd/forum_esd_2010/program/program12_01/pdf/presentation5.pdf (accessed on 25 June 2010). 
50. SIGAR (Special Inspector General for Afghanistan Reconstruction). Inadequate Planning for ANSF Facilities Increases Risks for \$11.4 Billion Program; SIGAR Audit-11-6; Office of the Special Inspector General for Afghanistan Reconstruction: Arlington, VA, USA, 2011.

51. SIGAR. Better Planning and Oversight Could Have Reduced Construction Delays and Costs at the Kabul Military Training Center; SIGAR Audit-12-2; Office of the Special Inspector General for Afghanistan Reconstruction: Arlington, VA, USA, 2011.

52. The Asia Foundation. Afghanistan in 2008: A Survey of the Afghan People; The Asia Foundation: Kabul, Afghanistan, 2008. Available online: http:/ / asiafoundation.org/resources/pdfs/Afghanistanin2008.pdf (accessed on 12 January 2017).

53. Gompert, D.C.; Kelly, T.K.; Lawson, B.S.; Parker, M.; Colloton, K. Reconstruction under Fire: Unifying Civil and Military Counterinsurgency; RAND Corporation, National Defense Research Institute: Santa Monica, CA, USA, 2009.

54. Lawson, B.S.; Kelly, T.K.; Parker, M.; Colloton, K.; Watkins, J. Reconstruction under Fire: Case Studies and Further Analysis of Civil Requirements; RAND Corporation, National Defense Research Institute: Santa Monica, CA, USA, 2010.

55. Barfield, T. Afghan paradoxes. In Afghan Endgames: Strategy and Policy Choices for America's Longest War; Rothstein, H., Arquilla, J., Eds.; Georgetown University Press: Washington, DC, USA, 2012.

56. Gildrie, R.P. The enlightenment quest for peace. In Stability Operations and State-Building: Continuities and Contingencies; Kaufmann, G., Ed.; U.S. Army War College, Strategic Studies Institute: Carlisle, PA, USA, 2008; pp. 3-17.

57. Stavridis, J. The Comprehensive Approach in Afghanistan. Prism 2011, 2, 65-76.

58. The Asia Foundation. Afghanistan in 2016: A Survey of the Afghan People; The Asia Foundation: Kabul, Afghanistan, 2016. Available online: http://asiafoundation.org/publication/afghanistan-2016-surveyafghan-people/withdataathttp:/ / asiafoundation.org/wp-content/uploads/2016/12/2016_Survey-ofthe-Afghan-People_full-survey.Jan2017.pdf (accessed on 12 January 2017).

59. UN-Habitat (United Nations Habitat). State of Afghan Cities; UN-Habitat: Nairobi, Kenya, 2015; Volume-I English. Available online: https:/ / unhabitat.org/books/soac2015/ (accessed on 18 January 2017).

60. UN-Habitat. State of Afghan Cities; UN-Habitat: Nairobi, Kenya, 2015; Volume II. Available online: https: / / unhabitat.org/books/soac2015_volume2/ (accessed on 18 January 2017).

61. Reisig, M.D.; Parks, R.B. Experience, quality of life, and neighborhood context: A hierarchical analysis of satisfaction with police. Justice Q. 2000, 17, 607-630. Available online: http:/ / www.tandfonline.com/doi/ abs /10.1080/07418820000094681\# (accessed on 22 September 2017). [CrossRef]

62. Sunshine, J.; Tyler, T.R. The role of procedural justice and legitimacy in shaping public support for policing. Law Soc. Rev. 2003, 37, 513-548. [CrossRef]

63. Benedict, W.R.; Brown, B.; Bower, D.J. Perceptions of the police and fear of crime in a rural setting: Utility of a geographically focused survey for police services, planning, and assessment. Crim. Justice Policy Rev. 2000, 11, 275-298. [CrossRef]

64. Agoglia, J.; Dziedzic, M.; Sotirin, B. Measuring Progress in Conflict Environments (MPICE): A Metrics Framework; United States Institute of Peace Press: Washington, DC, USA, 2010.

65. Apparicio, P.; Séguin, A.M. Measuring the accessibility of services and facilities for residents of public housing in montreal. Urban Stud. 2006, 43, 187-211. [CrossRef]

66. Bayley, D.H. Policing for the Future; Oxford University: New York, NY, USA, 1994.

67. Bayley, D.H. Law enforcement and the rule of law: Is there a tradeoff? Criminol. Public Policy 2002, 2, 133-154. [CrossRef]

68. Bradford, B.; Murphy, K.; Jackson, J. Officers as mirrors: Policing, procedural justice and the (re)production of social identity. Br. J. Criminol. 2014, 54, 527-550. [CrossRef]

69. Gelman, A.; Fagan, J.; Kiss, A. An analysis of the New York City Police Department's "Stop-and-Frisk" Policy in the context of claims of racial bias. J. Am. Stat. Assoc. 2007, 102, 813-823. [CrossRef]

70. Sampson, R.J.; Raudenbush, S.W.; Earls, F. Neighborhoods and violent crime: A multilevel study of collective efficacy. Science 1997, 277, 918-924. [CrossRef]

71. Jang, H.; Joo, H.J.; Zhao, J.S. Determinants of public confidence in police: An international perspective. J. Crim. Justice 2010, 38, 57-68. [CrossRef] 
72. Ene, M.; Leighton, E.A.; Blue, G.L.; Bell, B.A. Multilevel models for categorical data using SAS ${ }^{\circledR}$ PROC $^{-1}$ GLIMMIX: The basics. In Proceedings of the 2015 SAS Global Forum, Dallas, TX, USA, 25-29 April 2015. Paper 3430-2015.

73. Garson, G.D. Hierarchical Linear Modeling: Guide and Applications; SAGE Publications Inc.: Thousand Oaks, CA, USA, 2012.

74. Heck, R.H.; Thomas, S.L. An Introduction to Multilevel Modeling Techniques, 2nd ed.; Routledge: New York, NY, USA, 2009.

75. Hox, J.J. Multilevel Analysis: Techniques and Applications; Lawrence Erlbaum Associates: Mahwah, NJ, USA, 2002.

76. Klein, K.J.; Kozlowski, S.W. Multilevel Theory, Research, and Methods in Organizations: Foundations, Extensions and New Directions; Jossey-Bass: San Francisco, CA, USA, 2000.

77. Raudenbush, S.W.; Bryk, A.S. Hierarchical Linear Models: Applications and Data Analysis Methods, 2nd ed.; SAGE Publications Inc.: Thousand Oaks, CA, USA, 2002.

78. Smiley, W.; Leighton, E.; Guo, Z.; Ene, M.; Bell, B.A. An intermediate guide to estimating multilevel models for categorical data using SAS ${ }^{\circledR}$ PROC GLIMMIX. In Proceedings of the Southeast SAS User Group (SESUG) Conference 2015, Savannah, GA, USA, 27-29 September 2015. Available online: https: / / pdfs.semanticscholar.org/f6c9 / 4e786293e4535d97c1853a002484669b752f.pdf (accessed on 17 May 2017).

79. Schabenberger, O. Introducing the GLIMMIX procedure for generalized linear mixed models. In Proceedings of the SAS Users Group International Conference-SUGI 30, Philadelphia, PA, USA, 10-13 April 2005.

80. O'Connell, A.A.; McCoach, D.B. Multilevel Modeling of Educational Data; Information Age Publishing: Charlotte, NC, USA, 2008.

81. Sztompka, P. Society in Action: The Theory of Social Becoming; University of Chicago Press: Chicago, IL, USA, 1991.

82. Brandl, S.L.; Frank, J.; Worden, R.E.; Bynum, T.S. Global and specific attitudes toward the police: disentangling the relationship. Justice Q. 1994, 11, 119-134. [CrossRef]

83. Cao, L.; Frank, J.; Cullen, F.T. Race, community contest, and confidence in the police. Am. J. Police 1996, 15, 3-22. [CrossRef]

84. Cao, L.; Hou, C.A. Comparison of confidence in the police in China and on the United States. J. Crim. Justice 2001, 29, 87-99. [CrossRef]

85. Emadi, H. Culture and Customs of Afghanistan. Greenwood Publishing Group: Westport, CT, USA, 2005.

86. UNODC (United Nations Office on Drugs and Crime). Sustainable Development in an Opium Production Environment: Afghanistan Opium; Survey Report 2016; Islamic Republic of Afghanistan Ministry of Counter Narcotics: Kabul, Afghanistan, 2016. Available online: https:/ / www.unodc.org/documents/cropmonitoring/Afghanistan/Afghanistan_sustainable_development_for_web.pdf (accessed on 22 September 2017).

87. Abdullah, A. Afghanistan's Chief Executive Is Hopeful for U.S. War Strategy; National Public Radio Interview, 16 November 2017. Available online: https://www.npr.org/2017/11/16/564538141/ afghanistans-chief-executive-is-hopefull-for-u-s-war-strategy (accessed on 17 November 2017).

(C) 2019 by the authors. Licensee MDPI, Basel, Switzerland. This article is an open access article distributed under the terms and conditions of the Creative Commons Attribution (CC BY) license (http://creativecommons.org/licenses/by/4.0/). 